\title{
Effective Use of Nature in Educational Spaces Design
}

\author{
Farhang Mozaffar \\ Assistant professor \\ School of architecture and urban \\ engineering -Iran University of Science \& \\ Technology - Narmak - Tehran - Iran \\ e-mail: F.Mozaffar@aui.ac.ir
}

\author{
Seyedeh Somayeh Mirmoradi \\ $\mathrm{PhD}$ candidate \\ School of architecture and urban \\ engineering -Iran University of Science \& \\ Technology - Narmak - Tehran - Iran \\ e-mail: mirmoradi81@gmail.com
}

DOI 10.5592/otmcj.2012.1.3 Research paper

\section{Keywords \\ children-educational space- nature- architecture- landscape}

\section{ONE OF THE MOST EFFECTIVE SPACES ON CHILDREN'S LIFE IS EDUCATIONAL}

SPACES, WHERE THE CHILDREN USUALLY SPEND LONG PERIOD OF THEIR LIFE THERE. According to various important aspects of outdoor and natural spaces in education and children's nurture skills, design of these spaces is an essential issue among the topics raised in designing educational spaces. Natural spaces at schools should provide three categories of children's needs, which are denominated to: "educational", "communal and physical", and "emotional" needs. For all of these categories, the special spaces and desirable designing have to be concerned to achieve the most efficient educational spaces. Furthermore, outdoor designing and natural spaces will affect on artificial spaces of schools, due to the strong relationship between them. In current study, the effect of those three mentioned categories has been evaluated on the designing of educational spaces. Also, the effect of each aspect has been considered separately to recognize which principles are required to design an idealistic educational space.

\section{Introduction}

Technology development has been effective in the children's lifestyle, especially in the big cities. Children have been separated from the routine living in the nature as their presence in nature has been limited. Researchers at the University of Maryland discovered that between 1981 and 2003, in a typical week, children lost over nine hours of discretionary time, and computer use doubled. Studies released in 2005 and 2006 by the Kaiser Family Foundation, concluded that children between the ages of 8 and 18 "spent an average of nearly 6.5 hours a day plugged in electronics" (Louv,2005,p.119). One of the measurable impact of this for young children is that preschooler's "risk for obesity increases by $6 \%$ for every hour of TV watched a day" (Linn, 2008, p.49) though the "childhood link between outdoor activity and physical health is clear.

Nowadays, the relationship between children and nature is being weakened and this problem should be improved by protecting the natural spaces at schools and the other public places which may be usable for children. Natural spaces at schools should provide three categories of children's needs which are denominated to: "educational", "communal and physical", and 
"emotional" needs. Although several investigations have been performed about the importance of natural spaces at schools, none of them considered these three related factors at the same time.

In This paper, the importance of natural spaces has been considered on children's development which includes "cognitional", "social and physical", and "emotional" development. Each of mentioned items has been explained and eventually, some architectural principles have been proposed for each of them.

\section{Educational spaces design}

It has been observed that for nearly two centuries, public schools have been built largely as a reflection of the factory model of learning that fill a group of children with knowledge in a confined space called a classroom. A vast number of people -architects and educators alike-have called this model into question (Boss, 2001; Bullock \& Foster-Harrison, 1997; Davis, 2004; Day, 2000, 2001; Fiske, 1995; Gardner, 1999; Lamm, 1986; Nair, 2002; Papert, 1993).

These critical approaches lead to changing in school's curriculums and school's spaces design. Educators and architects do researches on how different aspects of school spaces design affect on different aspects of children's development. Researchers conclude that students who attend schools that are well maintained, meet safety standards, and are kept clean, are also more likely to demonstrate higher levels of academic performance than those students in schools with leaking roofs, broken windows, missing toilet stalls, and dark classrooms (Berner,1992, 1995; Boss, 2001; Kolleeny, 2003; Lezotte \& Passalacqua, 1978; Peters,2003).For decades, engineers, architects, psychologists, and educators have also examined the role that lighting and color, for instance, play in generating environments conducive learning and to prosocial behaviors (Dudek,2000; Hathaway, 1995; Luckiesh \& Moss, 1940; Muir, 2001; Rice, 1953; RittnerHeir, 2002; Romney, 1975; Sherman, 2001; Tanner, 2000).Some researchers and planners have demonstrated that the use of daylight in the context of a larger energy-efficient design is not only associated with higher levels of student performance, but can also be cost effective (Hathaway, 1995; Plympton, Conway, \& Epstein, 2000; Reicher, 2000). Studies have also focused on the detrimental effects of too much noise in the learning environment (Boss, 2001a; Chan, 1980; Tanner \& Langford, 2003),the importance of appropriate furniture (Bullock \& Foster-Harrison, 1997), and the need for inviting outdoor spaces including green areas and play areas (Tanner, 2000).

In current study the importance of nature in the school design to children development will be discussed. As the nature has different capabilities in children development, each of these capabilities should be noticed by architectures.

\section{Children and nature}

According to Moore and Wong (1997), active learning in outdoor settings stimulates all aspects of child development more readily than indoor environments. Natural environments seem to be associated with the cognitive development of children through opportunities for exploration, experimentation and play (Hart, 1994). Play is extremely important in the development of social skills, the development of gross and fine motor skills, and the utilization of excess energy (International Association for the Child's Right to Play, 1982). Outdoor environments are also important for effective environmental education.

Increasingly, evidence suggests that the development of environmentally responsible behaviors is associated with a combination of both formal learning and informal, positive experiences in the natural world. Extensive research has substantiated the physiological, psychological, intellectual, social and altruistic benefits of connecting children with nature:

- Increased concern for the environment. (palmer. 1993)

- Increased sense of wonder and imagination (Cobb, 1977; Wilson, 1997)

- Improved ability to concentrate (Taylor, 2001)

- Increased powers of observation and creativity (Crain, 2001)

- Increased motivation for life-long learning (Wilson, 1997)

- Improved awareness, reasoning, and observational skills (Pyle, 2002)

- Improved personal skills including confidence, social skills, self-efficacy) (Dillon,J., Morris, M., O’Donnell, L., Reid, A., Rickinson, M.,\&Scott, W., 2005)

- Reduced stress/greater ability to deal with adversity (Wells\&Evans, 2003)

- Increased language and collaborative skills (Moore\&Wong, 1997)

- Increased development of senses (Louv, 2005)

- Increased knowledge and understanding of geographical, ecological or food production process (Dillon, J., Morris, M., O’Donnell, L., Reid, A., Rickinson, M.,\&Scott, W., 2005)

- Increased analytical, problemsolving, and critical thinking skills, and integration of math, science, language arts, social sciences and other subjects (Bartosh, 2006) Keeler (2008) described the natural world as "a great friend and teacher to young children" because it "offers infinite opportunities for wonder and learning, with surprises around every corner". The "power of nature to teach 
and inspire" should be reason enough to make weaving "nature into the lives of young children" a priority (p.55)

Natural spaces at schools should provide three categories of children's needs. These needs are:

- Educational needs

- Communal and physical needs

- Emotional needs.

The physical space of schools could have positive effects on children's development when the mentioned needs would be provided. These three mentioned aspects will be further discussed later in this paper:

\section{Impact of natural environments on children's education:}

\section{Indoor of schools building:}

Nature presence in schools impacts on quality of learning indoor of schools. The link between green school grounds and learning is supported by a number of studies (Moore\&Wong, 1997; Malone\&Tranter, 2003). A mounting body of evidence likewise indicates that green settings generally may help to promote increased concentration (Grahn, 1997), attention functioning (Taylor, 2001; Wells, 2000) and selfdiscipline (Taylor, 2002). Research found that classroom plants consistently led to improve performance in spelling, mathematics and science. Plants in the classrooms can improve student performance. (Daly et al, 2010) Green environments can play a particularly important role for young people who have difficulty learning in the formal school environment, who are reluctant learners, who have difficulty concentrating or who suffer from Attention Deficit Disorder (ADD) (Pentz, 1998). It has been shown, for example, that children with ADD have fewer attention deficit symptoms after spending leisure time in natural settings (Taylor, 2001; Kuo, 2004). The positive relationship between physical activ- ity and academic success has been repeatedly demonstrated (Symons, 1997).

\section{Outdoor of schools building:}

Natural environments tend to allow children to manipulate and change "pieces" of their surroundings i.e. in forested areas where forts can be built or in sandy areas where children can dig and create structures. Bjorklid (1982) notes Jean Piaget's comment that: "children should be able to do their own experimenting, their own research...In order for a child to understand something he must construct it for himself, he must reinvent it...if in the future individuals are to be formed who are capable of creativity and not simply repetition." This statement reinforces the importance of explorative behaviors in development of a child's intellect, particularly their problem solving abilities and creativity. Natural settings seem to support this learning process.

Natural Schoolyards also encourage the type of hands-on experiences that are necessary for effective environmental education. Research shows that students better absorb and retain math, science, language arts, and other skills that incorporate their immediate environment and use all five senses (Lieberman and Hoody 1998). Howard Gardner (1991) suggested that the value of learning in nature( what he called "outdoor education") is that the learning is not bound to school settings; rather nature education fosters connected knowing that is not separate from but an integral part of life.

Inasmuch, outdoor experience allows the children to interpret and extrapolate the differences of features and phenomena from the indoor experience. When children play in natural environments, their play is more diverse. There is a higher prevalence of imaginative and creative play that fosters language and collaborative skills (Moore \& Wong 1997, Taylor, et al. 1998, Fjortoft 2000). Exposure to natural environments improves children's cognitive development by increasing their awareness, reasoning and observational skills (Pyle 2002). Early experiences with the natural world have been positively linked with the development of imagination and the sense of wonder (Cobb 1977, Louv 1991). Wonder is an important motivator for lifelong learning (Wilson 1997).

The children are emotionally affected to outdoor settings through direct, literal, or tactile contacts. The cognition enables the children to be active constructors of their own knowledge, leading them to discover certain logical truths about objects and concepts of the environment. Therefore, active experience with the environment affords the children to form logical thought and able to draw logical inferences from the facts that they are given (McDevitt and Ormrod, 2002). Direct contacts with the features and factors of the environment permit the children to explore, imagine and discover (Olds, 1989; Kahn, 2002). Consequently, the natural environment at schools can improve educational purposes in both indoor and outdoor of schools building. Several reasons show the positive effects of nature on children's education which will be further discussed:

\section{Natural environment and outdoor education:}

Outdoor education is a cultural construct which it is thought about and applied in different ways within and between countries. For example, the European Institute for Outdoor Adventure Education and Experiential Learning identifies outdoor education as comprising "outdoor activities"," environmental education" and "personal and social development".

What is common to these ideas is that the teacher and pupils pursue learning outcomes beyond the classroom. These ideas don't suggest that outdoor education is a better form of learning than class-based learning. These suggest that some learning is 
better suited out-of-doors and that there are good educational reasons for identifying and capitalizing on these opportunities. In this way class-based learning can be integrated with outdoor learning.

This is very much in the tradition of integrated holistic education. It was the type of approach whose historical roots lie in the work of, for example, Johann Pestalozzi, John Dewey, Paolo Freiere and Patrick Geddes.

Outdoor environmental education develops knowledge, attitudes and skills across the whole curriculum - it is knowledge about the environment ('Head'), developing skills through going out in the environment ('Hands') which in turn creates the caring attitudes needed for the environment ('Heart'). Many aspects of the curriculum especially in science, geography, physical education and art can only be taught effectively through outdoor experience, and the school grounds are the obvious place to start. Teachers need the confidence to use this 'outdoor classroom'

\section{Natural environment and experiential learning:}

Outdoor education is in direct relationship with experiential learning. Experiential learning is generally concerned with learning that depends on first-hand experiences which connect the learner with real people and real issues. It is often associated with informal education although this is not exclusively so. Furthermore, it is generally considered to be a lifelong process integrating education, work and leisure. Experiential learning is based on the premise that the learner learns best by doing and one of the teaching methods often employed is based on problem solving approaches. Experiential learning improves in natural environment because of rich of experiential resources in nature.

According to the Scottish Consultative Council on the Curriculum (1996),
Learning is messy. We rarely learn anything by proceeding along a single path to pre-determined outcomes'. It seems that we understand the world by relating pieces of information to others and fitting it all together. As multi-sensory animals we understand the world through sight, sound, taste, smell and touch. We also relate to events in ways which are intellectual, physical, emotional, aesthetic and spiritual. Whilst it may be possible to experience an event through a single sense and know it in a single way, this is not the norm. The more complex the experience, the more ways there are of experiencing it and knowing it.

In light of this it seems that the more ways an event is known, the better the chance that it will be understood. So it makes sense for those involved in 'helping others to learn' to provide experiences that allow the learner to use all his or her senses in experiencing and 'internalizing' these experiences.

\section{1-2-3- Natural environment and Multiple Intelligences:}

Closely related recent work by Howard Gardner (1999) has led to the suggestion that the simplistic notion of a single 'intelligence' is outdated. He argues that for each of these there are at least eight facets to intelligence, and that we have developed all of these to a lesser or greater extent. He lists:

- Musical intelligence;

- Bodily-kinesthetic intelligence;

- Logical-mathematical intelligence;

- Linguistic intelligence;

- Spatial intelligence;

- Interpersonal intelligence;

- Intrapersonal intelligence.

- Naturalist Intelligence

He and others are critical of the traditional education system because it favours logical mathematical intelligence, arguing that this limits the potential for those who are better suited to learning in other ways. Others have gone further, suggesting that this leads to dissatisfied learners who are troublesome at school and have poor education prospects. Among different types of intelligence, the naturalist intelligence develops when it expose to the natural environment directly. Furthermore Bodily-kinesthetic intelligence, Musical intelligence, interpersonal intelligence could develop in natural contexts better than the other spaces.

\section{Impact of natural environments on children's social and physical development:}

\section{Children and Play:}

Researchers have identified a series of social and cognitive categories of play based on a child's stage of development. Cooperative and symbolic play is typical of primary aged students (Parten, 1932). Construction and functional (or exercise) play becomes increasingly integrated with other forms of recreation as children develop (Smilansky, 1968). Many late primary-age children are ready for games with rules (Piaget, 1962). It is certainly evident that the various stages in play development necessitate provisions for all categories of play in both the outdoor and indoor environment. Play theory suggests that it is an important tool for developing social skills, culture and community (Hart, 1994). Play is part of the learning experience (Moore, 1986); it allows children to learn negotiation skills and to be creative (Parker, 1998). Play," the work of children", has a key role in two major areas of development-social development (Garvey, 1977; Greif, 1977; Hartup, 1978; Rubin, Fein, Vandenberg, 1983) and cognitive development (Piaget, 1962; Sylva, 1974; Sylva, Bruner\&Geonova, 1976).

Dr. Ginsburg's (2007) clinical report to the American academy of pediatrics noted that "play is so important to optimal child development that has been recognized by the United Nations 
High Commission for human Rights as a right of every child" (p.182) referencing numerous research-based publications, Ginsburg identified multiple benefits of play:

- Important to healthy brain development

- Allows children to use creativity while developing their imagination, dexterity, and physical, cognitive, and emotional strength.

- Allow children to create and explore a world they can master, conquering their fears while practicing adult roles.

- Helps children develop new competencies that lead to enhanced confidence and resiliency to face future challenges.

- Unstructured play allows children to work in groups, share, negotiate, resolve conflicts, and learn selfadvocacy skills.

- Child-driven play allows children to practice decision-making skills, move at their own pace, discover their own areas of interest, and engage fully in their passions.

- Builds active, healthy bodies.

- Is integral to the academic environment- helps children adjust to the school setting and enhances children's learning readiness, learning behaviors, and problem-solving skills.

- Unscheduled play that allows time for peer interactions are important components of social-emotional learning.

- Less verbal children express themselves through play, giving parents (and teachers) a better understanding of their perspectives. (Gisburg, 2007)

He stressed that play is "essential" to children's cognitive, physical, social and emotional wellbeing and is important to children's healthy brain development.

If school grounds are to realize their potential to promote physical activity, they must offer opportunities for forms of active play that appeal more broadly to children of varying interests and abilities. This is where green school grounds stand to make an important contribution.

If the social environment is fun, peaceful and welcoming, and children are feeling emotionally safe, then their interest in play and physical activity will undoubtedly increase. Conversely, if a play space is hostile, exclusive or overly challenging, then children will be less inclined to actively participate (Moore \&Wong, 1997; Dyment, 2006). Green school grounds can play a significant role in promoting physical activity. Through greening, school grounds diversify the play repertoire. Complementing the competitive games supported by asphalt and turf playing fields, green school grounds invite children to get moving in ways that nurture all aspects of their health and development. Of particular significance is the potential to encourage moderate and light levels of physical activity by increasing the range of enjoyable, non-competitive, open-ended forms of play at school.

\section{Play in nature:}

Play in outdoor environments stimulates all aspects of child development more readily than indoor environments (Moore \& Wong 1997). Through sensorial and motoric activities with peers and adults the children rapidly develop their language and communication skills. Their physical movement is much influenced by the functions of the features that they get in contact including furniture and toys in the indoors (Olds, 1987), and plants and animals in the outdoors (Kahn, 2002).

In middle childhood, children are genetically programmed for exploration of the world and bonding with nature (Cobb, 1969). That is, they learnt on how the world works in evocative way, their logical reasoning only about concrete objects that are readily observed. As such the children are active in grasping and understanding the natural world through play (Moore and Young, 1978). The play stimulates their cognitive faculties of sight, touch, taste, audio and olfactory. The experience involves the "process of developing and refining fundamental movement skills in a wide variety of stability, locomotors and manipulative movements" (Gallahue, 1993 pp. 39-40).

Children prefer natural environments for play. Titman's (1994) finding that children value and prefer natural environments to urban and built environments and that they associate adventure, challenge and risk with being outdoors is certainly striking. These associations suggest that contact with nature promotes the types of play that allows children to challenge themselves and develop self-esteem

Outdoor settings may be an especially interesting context in which to study play because creative play may be more likely in outdoor spaces than in indoor spaces.

A number of studies have indicated that features of the physical environment may affect play behavior(Ainsw orth\&Bell,1974;Clarke,Stewart,1973; Wachs,1978; Yarrow, Rubenstein\&Ped ersen,1975) .furthermore, theorists in landscape architecture (Hayward,Roth enberg\&Beasley,1974;Nicholson,1971) and leisure studies (Aguilar,1985) have proposed that physical settings affect the creativity of play.

Moore (1989) presented an intriguing collection of anecdotal evidence and argued that children played quite creatively in an outdoor space when playing with readily available plant materials.

Kirkby's (1989) study featured such a comparisons and found more dramatic play in the "green" spaces than in the built space. Children who play regularly in natural environments show more advanced motor fitness, including coordination, balance and agility, and they are sick less often (Grahn, et al.1997, Fjortoft \& Sageie 2000). 


\section{Social behavior in natural environment:}

Green school grounds are encouraging positive changes in student play behavior. Researchers have likewise documented that emphasis on the positive influence of exposure to green spaces on social behavior (Taylor, Wiley, Kua\&Sullivan, 1998; Cheskey, 2001; Wells\&Evans, 2003). A more recent study has linked outdoor play to stronger social skills and increased creative development (Miller, Tichota, and White 2009).

Wells and Evans (2003) concluded that the greater the amount of exposure to nature, the greater the benefits. When children engage in play in indoor environments, they play seems to be more diverse. They are more likely to engage in creative and imaginative play that fosters the development of language and collaboration skills (Taylor, Wiley, Kua\&Sullivan, 1998; Fjortoft\&Sageie, 2000; Moore \&Wong, 1997).

Children have opportunities to develop social skills as they engage in play with their peers, and Moors (1996) suggested that children who play together in nature have more positive feelings towards one another. Researchers have concluded that play in diverse, natural environments tends to reduce or eliminate anti-social behaviors such as bullying and violence (Coffey, 2001; Malone\&Tranter, 2003; Moore\&Cosco, 2000).

The architecture and its landscape is a social space where children play with peers or adults and create friendship, acquaintanceship, reduced social regressions and reduced social withdrawals (Ladd, 1999). These are progressive responses of children's social development (Ladd and Coleman, 1993; Ladd and Price, 1993). This is because during social play children expand their cognition of the place by assimilating the actions of others particularly peers (McDevitt and Ormrod, 2002). Natural environ- ments stimulate social interaction between children (Moore 1986, Bixler et al. 2002).

\section{Impact of natural environments on children's emotion and wellbeing:}

The outdoor space is spacious and open towards the surrounding that affords the children to move more freely than inside the building. It is a space that their senses are readily stimulated by greenery and animals (Kahn, 2002). Its microclimate is natural and dynamic; changes in temperature and wind and the presence of rain or snow (Prescott, 1987; Olds, 1989). Such environment affords the children to understanding the facts that nature is not man-made, it is dynamic and timeless (Prescott, 1987).

The empirical studies by Fjorfort (2004) and Said (2007) implicate that kindergarten or hospital ward should be integrated with the outdoor spaces especially greenery. The architecture not only a milieu for learning or health recovery but also a physical setting that triggers the positive behavioral responses such as place attachment and place identity.

Authors have described the emotional and ecological benefits of spending time in nature. When children play outdoors, in a rich environment, it instills in them a sense of peace and being at one with the world (Craine, 2001). Spending time in nature is important for children to develop their eco-psychological selves. Phenice and Griffore (2003) suggested that children's sense of self needs to develop in conjunction with and as a part of nature and that regular, positive interaction with nature are instrumental to helping children develop a respect for the environment. When children play in nature, the result is a marked increase in children's interest in and knowledge of nature (Fjortoft, 2001).

An affinity to and love of nature along with a positive environmental ethic, grow out of regular contact with and play in the natural world during early childhood. (Chawla 1988; Wilson 1993; Sobel 1996, 2002 \& 2004; Wilson 1997; Kahn 1999; Kals et al. 1999; Moore \& Cosco 2000; Bixler et al. 2002; Kals \& Ittner 2003; Schultz et al. 2004).

Spending time in nature has been shown to reduce stress and benefit treatment of numerous health conditions (Kahn, 1999). Time in nature diminishes the impact of stress on children, and helps them handle adversity (Wells\& Evans, 2003), which is critical to helping children cope in this increasingly hurried and pressured society. Peter Kahn identified "over one hundred studies that confirm that one of the main benefits of spending time in nature is stress reduction" (Louv, 2005, p.49)

Numerous studies have shown that indoor plants provide a number of benefits for health and well being, including decreases in illness symptoms, increases in work performance and job satisfaction, and lifting of spirits (Burchett et al, 2010)

Louv (2005) indicated that although "countless children who suffer from mental illness and attention disorders do benefit from medication... new evidence suggest that the need for such medications is intensified by children's disconnection from nature" (p.48). Ultimately as young children "spend less and less of their lives in natural surroundings, their senses narrow, physiologically and psychologically, and this reduces the rich of the human experience" (p.3)

\section{Designing strategies:}

We should consider three categories of needs in children in order to effective use of nature in educational spaces design. These are some strategies to design natural spaces in schools according to needs categories. Figs 1 up to 6 show some built examples that are illustrated for more clarification of these strategies: 


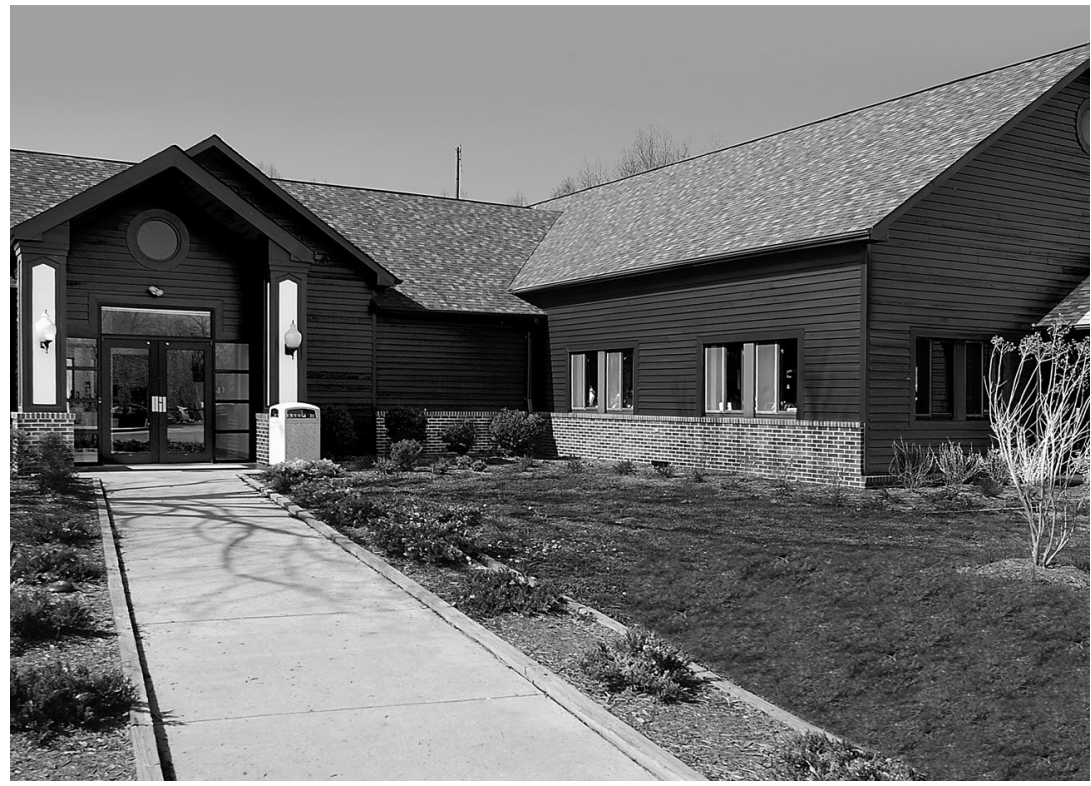

Figure 1: Montessori School with use of natural environment in education awakens a passion for exploration; nurtures curiosity, creativity, and imagination for children- US, Maryland

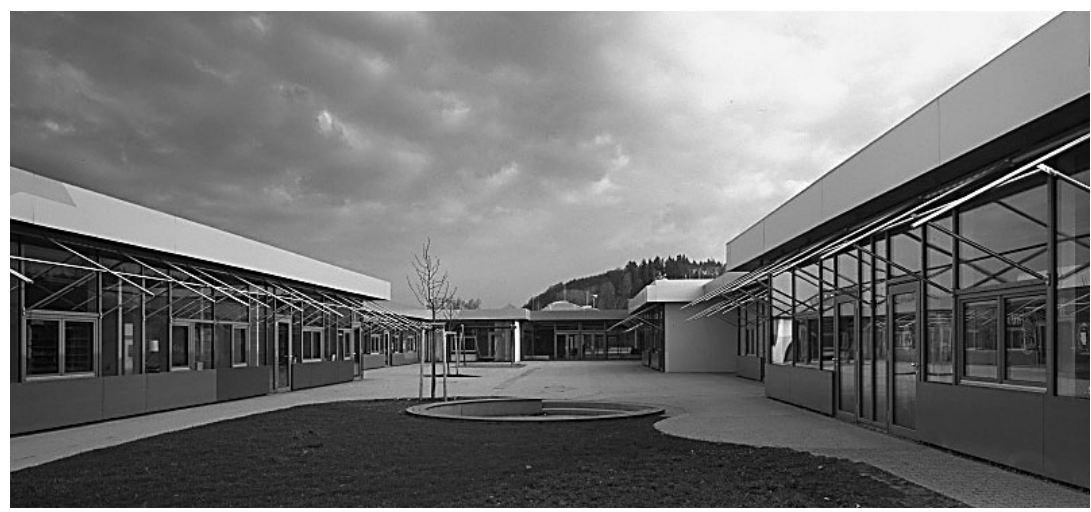

Figure 2: School is a series of one-story buildings around a central courtyardGermany, Herbrechtingen

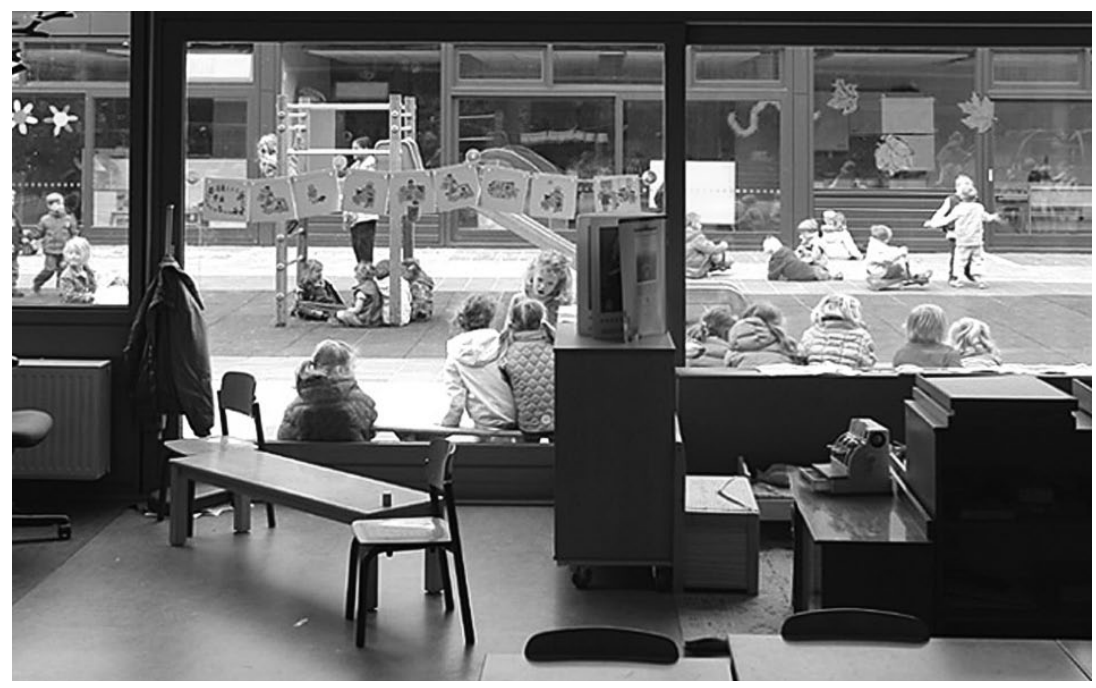

Figure 3: The sliding doors on the ground level offer the possibility to use part of the court for the classrooms- Netherlands, The Hague
1 - Designing strategies for develop educational Needs:

1-1 - Creating connection between classroom and outdoor environments to combine indoor education with outdoor education. (Fig 1)

1-2 - creating a natural laboratory next the classroom for children's direct experience in nature.

1-3 - Creating educational terraces, places for growing various plants, that children can observe their growth, these spaces should be available through the classrooms. 1-4 - Create space for planting and aquaculture in school's yards.

1-5 - design school's yards with based on training needs of different courses (such as math and arts).

\section{2 - Designing strategies for} develop communal and physical needs:

\section{2-1 - creating spaces for collective} games in natural environment of schools. (Figs 2, 3)

2-2 - promoting children's social interaction through designing play spaces suitable for all ages and creating small gardens around the play spaces. (Fig 4)

2-3 - Design some intellectual board games in the school yard.

2-4 - Design spaces for sitting a group of children among the natural spaces of schools. (Fig 5)

\section{3 - Designing strategies for} develop emotional needs:

3-1 - creating wide views to natural

spaces from closed spaces in school. (Fig 6)

3-2 - design accessibility between the inner spaces and outside of the schools. (Figs 2, 3)

3-3 - Creating some beautiful flowers and plants in the interior spaces of schools. (Figs 5,6 )

3-4 - generate planting by children in inner and outer spaces of schools. 


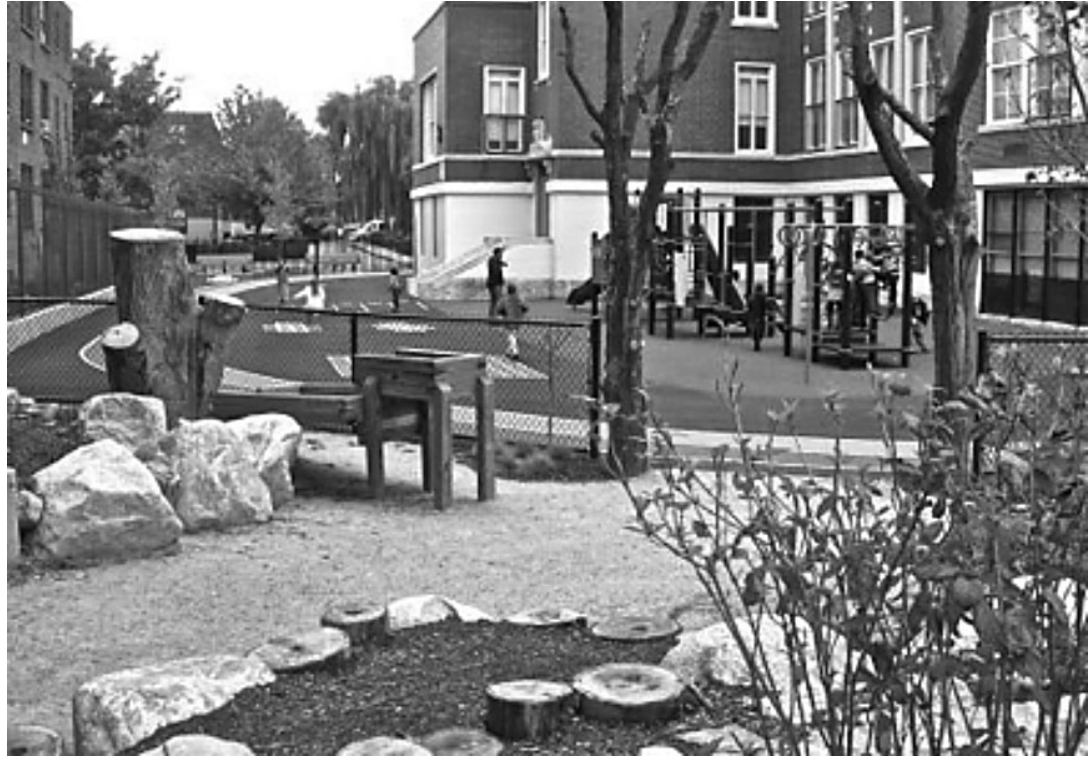

Figure 4: Play spaces in natural environment of school for social and physical development of children

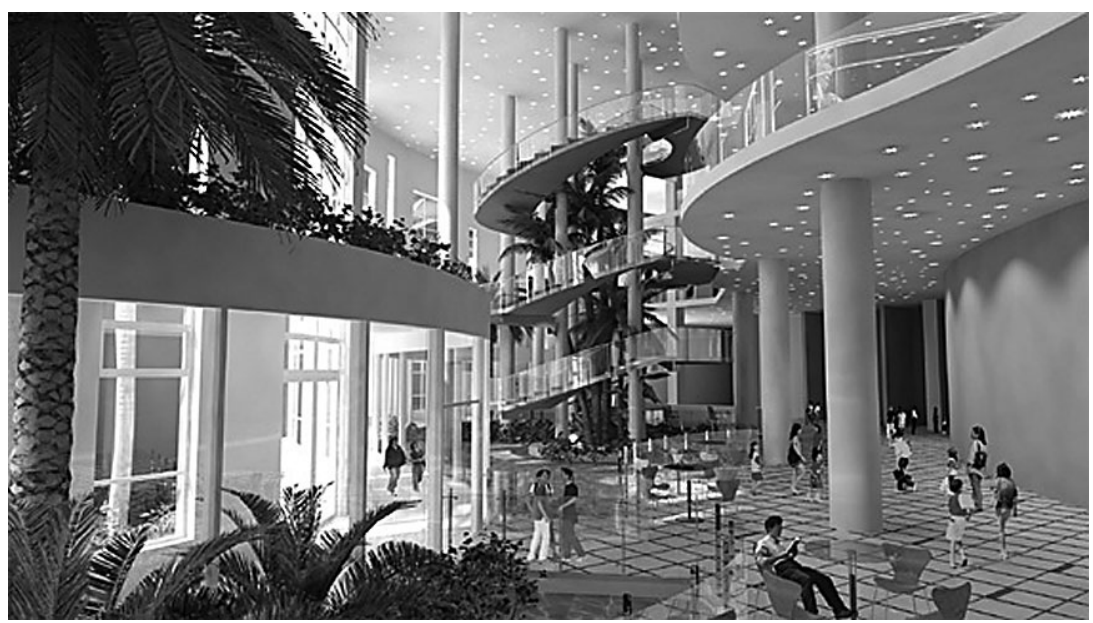

Figure 5: Use of watering pool and green spaces in communal indoor spaces of school- United Arab Emirates, Dubai

3-5 designing Schools with fountains, pools and, green spaces to improve aesthetic and sense of belonging to space in children. (Fig 6)

\section{Conclusion}

Generally, natural spaces at schools should provide three categories of children's needs which are denominated to: "educational", "communal and physical" and, "emotional" needs. Providing these needs can be changed the physical space of school to an effective environment for chil- dren's development. Natural spaces should be useful for children' cognitive development and it should be increased knowledge about nature, attitude to nature and, skills develop in natural spaces. In addition, natural spaces should be appropriate for physical and social development of children. Social spaces which design in natural environments should provide interaction between children. In addition, these spaces should be designed to provide emotional needs of children.

Note that each of mentioned factors

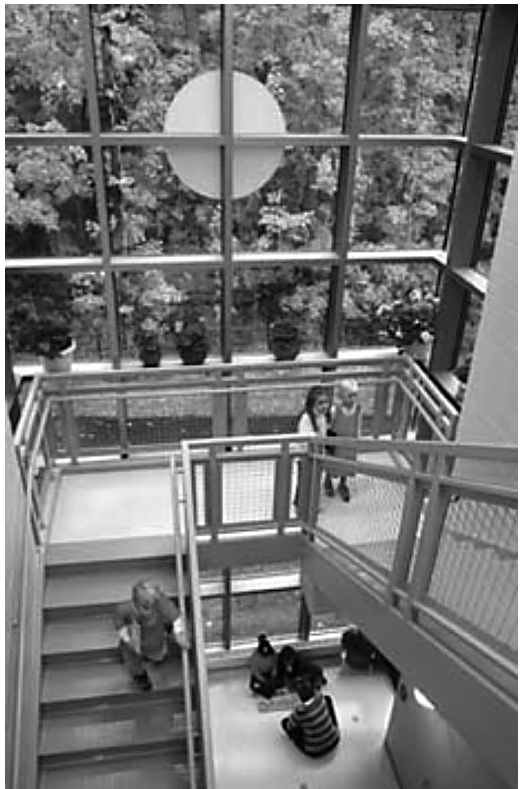

Figure 6: Glass enclosed stairways connect indoor and outdoor of schoolUS, Ohio need to special spaces and design. Moreover, outdoor and natural spaces designing effect on design artificial schools spaces, because of the relationship between these two spaces. Therefore, Designers should pay attention to each of these aspects that could be performed with different strategies. These strategies may be different in various schools. Table 1 , indicates some of these strategies which could be used at most schools. Figs 1 up to 6 show some built examples that are illustrated for more clarification of these strategies. 


\begin{tabular}{|c|c|c|c|}
\hline \multirow{2}{*}{\multicolumn{2}{|c|}{\begin{tabular}{l}
\multicolumn{1}{c}{ Goals } \\
Develop Needs of children \\
in natural environment of \\
school
\end{tabular}}} & \multirow[b]{2}{*}{ Designing strategies } & \multirow[b]{2}{*}{$\begin{array}{l}\text { Designing } \\
\text { strategies in } \\
\text { schools }\end{array}$} \\
\hline & & & \\
\hline \multirow{5}{*}{1} & \multirow{5}{*}{$\begin{array}{l}\text { Develop Educational } \\
\text { Needs }\end{array}$} & Combine indoor education with outdoor educational spaces. & Fig 1 \\
\hline & & Creating natural laboratory next the classroom. & - \\
\hline & & Create educational terraces available through the classrooms. & - \\
\hline & & Create space for planting and aquaculture in school's yards. & - \\
\hline & & Design school's yards with based on training needs of different courses. & - \\
\hline \multirow{4}{*}{2} & \multirow{4}{*}{$\begin{array}{l}\text { Develop Communal } \\
\text { and Physical Needs }\end{array}$} & Creating spaces for collective games in natural environment of schools. & Figs 2, 3 \\
\hline & & Designing play spaces with small gardens around them. & Fig 4 \\
\hline & & Design some intellectual board games in the school yard. & - \\
\hline & & Design spaces for sitting a group of children among the natural spaces of schools. & Fig 5 \\
\hline \multirow{5}{*}{3} & \multirow{5}{*}{$\begin{array}{l}\text { Develop Emotional } \\
\text { Needs }\end{array}$} & Creating wide views to natural spaces from closed spaces in school. & Fig 6 \\
\hline & & Design accessibility between indoor and outdoor of schools. & Figs 2, 3 \\
\hline & & Use the beautiful flowers and plants in the interior spaces. & Figs 5,6 \\
\hline & & Generate planting by children in inner and outer spaces of school. & - \\
\hline & & Designing Schools with outdoor use of water and green spaces. & Fig 6 \\
\hline
\end{tabular}

Table 1: Three aspects of children's needs that develop in natural environment of schools, proposed designing strategies for each of them and, built examples of design strategies.

\section{References:}

Ainsworth,M.D.S.,\&Bell,S.M.(1974).Motherinfant interaction and the development of competence.in K.J.Connolly\&J.S.Bruner(Ed s), The growth of competence (pp.97-118). New York: Academic Press.

Aguilar,T.E.(1985).Social and environment barriers to playfulness. In J.L.Frost \&S.Sunderlein (Eds), when children play: proceedings of the international conference on play and play environments. Wheaton,MD: Association for childhood education international.

Bartosh.O, Mayer-Smith.J \& Peterat.L, (2006) "Informal science learning on anurban farm: A study of teachers' and students' experiences in a long-termenvironmental education project," presented at the NARST 2006 Annual,Meeting, San Francisco, CA, United States

Berner, M. M. (1992)“Building Conditions, Parental Involvement, and Student Achievement in the District of Columbia Public School System." Urban Education 28, no. 1: 6-29.

Berner, M. M.(1995) "Buildings Matter: The Connection Between School Building Conditions and Student Achievement in Washington, DC." In Designing Places for Learning, edited by A. Meek, 85-87. Alexandria, VA: Association for Supervision and Curriculum Development.
Bixler, Robert D., Floyd, Myron E. \& Hammutt, William E. (2002), “Environmental Socialization: Qualitative Tests of the Childhood Play Hypothesis", Environment and Behavior, 34(6), 795-818

Bjorklid, P. (1982). Children's Outdoor Environment. Stockholm: Stockholm Institute of Education.

Boss, S. "Breaking out of the Box.(2001)" Northwest Education Magazine 6, no. 4.

Bullock, A. A. and E. S. Foster-Harrison. (1997)"Making the Best Decisions: Designing for Excellence!" Schools in the Middle 7, no. 2: 37-39.

Burchett,M. D.,Torpy,F.,Brennan,J.,\&Craig ,$A(2010)$. Greening the great indoors for human health and wellbeing. Final report to horticulture Australia Ltd.,Sydney,Aust.

Chan, T. C. (1980)“Physical Environment and Middle Grade Achievement.”, ERIC Document Reproduction Service, ED 198645.

Chawla, Louise, (1988) “Children's Concern for the Natural Environment”, Children's Environments, (5)3

Cheskey E. (2001), How schoolyards influence behavior. In: Grant T, Littlejohn G (eds). Greening School Grounds: Creating Habitats for Learning. Gabriola Island, Canada: New Society Publishers, 2001, 5-9.

Clarke-Stewart,K.A.(1973). Interactions be- tween mothers and their young children: characteristics and consequences.Monographs of the society for research in child development,38 (6-7,serial No.153)

Cobb, E. (1969). The ecology of imagination in childhood. In: Shepard, P. and McKinley, D. eds.

The Subversive Science: Essays toward an Ecology of Man. Boston: Houghton Mifflin, 122-132.

Cobb, E. (1977), The Ecology of Imagination in Childhood, New York, ColumbiaUniversity Press.

Coffey,A.(2001). Transforming School grounds, in Greening school grounds: Creating habitats for learning. Grant,T.\&Littlejohn,G.(Eds). Toronto,CA: Green teacher and Gabrolia Island, BC: New society publishers.

Crain, W. (2001), "how Nature Helps Children Develop”, Montessori Life, Summer 2001.

Daly, J, Burchett M and Torpy F (2010) Plants in the classroom can improve student performance

Davis, B. (2004) Inventions Of Teaching: A Genealogy. Mahwah, NJ: Lawrence Erlbaum Associates

Day, C. W. (2000). “Trends In School Design.” Learning By Design.

Day, C. W. (2001). "Rethinking School Design.” Learning By Design. 
Dillon,J.,Morris,M.,O’Donnell,L.,Reid,A.,Rick inson,M.,\&Scott,W.,(2005). Engaging and learning with the outdoors-the final report of the outdoor classroom in a rural context action research project, national foundation for education research, april,2005.

Dudek, M.(2001), Kindergarten Architecture: Space For The Imagination. 2nd Ed. Independence, KY: Spon Press.

Dyment JE, Bell AC.(2006), “our garden is color blind, inclusive and warm": reflections on green school grounds and social inclusion. Int J Incl Educ 2006, 1-15. Preview article

Fiske, E. B. (1995), "Systemic School Reform: Implications for Architecture.” In Designing Places For Learning, edited by A. Meek, 1-10. Alexandria, VA: Association for Supervision and Curriculum Development.

Fjortoft, I. \& J. Sageie (2000), “The Natural Environment as a Playground for Children: Landscape Description and Analysis of a Natural Landscape", Landscape and Urban Planning, 48(1/2), 83-97

Fjortoft, Ingunn (2001), “The Natural Environment as a Playground for Children: The Impact of Outdoor Play Activities in PrePrimary School Children", Early Childhood Education Journal 29(2), 111-117

Fjortoft, I. (2004). Landscape as Playspace:The Effects of Natural Environments on Children's Play and Motor Development. Children, Youth and Environments, 2, 14, 21-44.

Gallahue, D. L. (1993). Motor development and movement skill acquistion in early childhood education. In: Spodek, B. ed. Handbook of Research on the Education of Young Children, New York: Macmillan Publishing Co., 24-41.

Gardner,H.(1991). The tensions between education and development. Journal of moral development,20(2),113-125

Gardner, H. (1999),Intelligence Reframed: Multiple Intelligences For The 21st Century. New York: Basic Books.

Garvey, C (1977). Play. Cambridge, MA: Harvard University Press.

Grahn P, Martensoon F, Lindblad B et al.(1997), “Ute pa dagis". Stad and Land, nr 145 [Outdoor Daycare. City and Coun- try]. Hassleholm, Sverige: Norra Skane Offset.

Ginsburg ,K,(2007), The Importance of Play in Promoting Healthy Child Development and Maintaining Strong Parent-Child Bonds

Greif,E.B.(1977). Peer interaction in preschool children. In G.Webb(Ed),Social development in childhood. Baltimore: John Hopkins University Press.

Hart, R. (1994). The Right to Play and Children's Participation. Presented at: Article 31: the child's right to play, Birmingham, England.

Hartup,W(1978). Peer relations and the growth of social competence. In M.W.Kent\& J.E.Rolf(Eds), The primary prevention of psychopathology (vol.3). Hanover,NH: University Press of New England.

Hathaway, W. (1995), “Effects Of School Lighting On Physical Development And School Performance." The Journal Of Educational Research 88, no. 4

Hayward,D.G.Rothenberg,M.,Beasley,R .R.(1974). Children's play and urban playground environments: A comparison of traditional, contemporary and adventure playground types. Environment and behavior, 6,131-168.

Kahn Jr., Peter H. (1999), The Human Relationship with Nature, MIT Press, Cambridge,MA

Kahn, P. H. (2002). Children's Affiliations with Nature: Structure, Development, and the Problem of Environmental Generational Amnesia. In: Kahn, P. H. and Kellert, S. R. eds. Children and Nature, Cambridge: The MIT Press, 93-115.

Kals, E., Schumacher, D., \& Montada, L. (1999), "Emotional Affinity Towards Nature as a Motivational Basis to Protect Nature", Environment \& Behavior, 31(2), 178-202

Kals, Elisabeth \& Ittner, Heidi (2003), “Children's Environmental Identity, Indicators and Behavioral Impacts", in Identity and the Natural Environment: The Psychological Significance of Nature, Clayton, Susan \& Opotow, Susan (eds), MIT Press, Cambridge,MA

Keeler,R.(2008).Natural playscapes: Creating outdoor play environments for the soul.
Redmond,WA: Exchange Press.

Kirkbey,M.(1989).Nature as refuge in children's environments. Children's environments Quarterly,6(1),7-12.

Kolleeny, J. (2003), “K-12 Schools: As Good As It Gets." Architectural Record 191, no. 3 Kuo FE, Taylor AF.(2004), A potential natural treatment for attention-deficit/hyperactivity disorder: evidence from a national study. Am J Public Health.

Ladd, G. W. (1999). Peer relationships and social competence during early and middle childhood. Annual Review Psychology, 50, 333-359.

Ladd, G. W. and Coleman, C. C. (1993). Young Children's Peer Relatioships: Forms, Features and Functions. In: Spodek, B. ed. Handbook of Research on the Education of Young Children, New York: Macmillan Publishing Co. 57-76.

Ladd, G. W. and Price, J. M. (1993). Play styles of peer-accepted and peer-rejected children on the playground. In: Hart, C. H. ed. Children on Playgrounds: Research Perspectives and Applications, Albany: State University of New York Press, 44-48.

Lamm, Z. (1986). "The Architecture Of Schools And The Philosophy Of Education." Paper Presented At The Edusystems 2000 International Congress On Educational Facilities, Values, And Contents, Jerusalem, Israel, November 16-21, 1986. ERIC Document Reproduction Service, ED 283287.

Lezotte, L. W., and J. Passalacqua. (1978). "Individual School Buildings Do Account For Differences In Measured Pupil Performance." ERIC Document Reproduction Service,ED 164695.

Lieberman, Gerald A. and Linda Hoody, (1998). Closing the Achievement Gap: Using the Environment as an Integrating Context for Learning. San Diego, Calif.: State Education and Environment Roundtable

Linn,S.(2008). The case for make-believe: saving play in a commercialized world. NY: The New Press

Louv, Richard (1991), Childhood's Future, Doubleday, New York, NY

Louv, R.(2005). Last child in the woods: Saving our children from nature-deficit disor- 
der. NY: Algonquin Books of Chapel Hill.

Luckiesh, M., and F. K. Moss. (1940)“Effects of classroom lighting upon educational progress and visual welfare of school children." Illumination Engineering 35, 915-938.

Malone,K.\&Tranter,P.(2003). Children's environmental learning and the use, design, and management for schoolgrounds. Children,youth and environments,13(2).

Malone K, Tranter PJ. (2003)School grounds as sites for learning: making the most of environmental opportunities. Environ

Educ Res 2003; 9: 283-303.

McDevitt, T., \& Ormrod, J. (2002). Child development and education. Upper SaddleRiver, NJ: Merrill Prentice Hall.

Miller, Dana; Kathy Tichota; and Joyce White. (2009). Young Children Learn Through Authentic Play in a Nature Explore Classroom. Lincoln, Neb. Dimensions Foundation

Moore RC, Wong HH. (1997)Natural Learning: The Life History of an Environmental Schoolyard. Berkeley, CA: MIG Communications,

Moore, R.S. (1986). Childhood's Domain: Play and Place in Child Development. Berkley, CA: MIG Communications.

Moore,R.C.(1989).Plants as play props. Children's environments Quarterly,6(1),3-6.

Moore, Robin \& Cosco, Nilda, (2000), “Developing an Earth-Bound Culture Through Design of Childhood Habitats"

Moore, R. C. and Young, D. (1978). Childhood Outdoors: Toward a Social Ecology of the Landscape. In: Altman, I. and Wohlwill, J. F. eds. Children and the Environment New York: Plenum Press.

Moore,R.\&Cosco,N.(2000).D eveloping an earth-bound culture through design of childhood habitats. Natural Learning Initiative.Paper presented at the conference on people, Land, and sustainability: A Global View of Community Gardening, University of Nottingham,UK,September.

Muir, M. (2001)“A Model Program In A Remodeled Building." Northwest Education Magazine 6, no. 4

Nair, P. (2002). "But Are They Learning? School Buildings-The Important Unasked
Questions.” Paper Presented At The International Workshop On Educational Infrastructure, Guadalajara, Mexico, Feb, 2002.

Nicholson,S.(1971). The theory of loose parts. Landscape Architecture, 62, 30-34

Olds, A. R. (1987). Designing Settings for Infants and Toddlers. In: Weinstein, C. S. and David,T. G. eds. Spaces for Children: The Built Environment and Child Development, New York: Plenum Press, 117-138.

Olds, A. R. (1989). Psychological and Physiological Harmony in Child Care Center Design.Children's Environment Quarterly, 4, 6, 8-16.

Palmer,J.(1993). Development od concern for the environment and formative experiences of educators. Journal of environmental education,24,26-30

Parker, K. (1998). School Kids Haven't Outgrown Recess. Kentucky Connect. Lexington. April 13.

Parten, M. (1932). Social Play among preschool children. Journal of Abnormal and

Social Psychology 27 :243-269.

Papert, S. (1993), The Children's Machine: Rethinking School In The Age Of The Computer. NewYork: Basic Books.

Pentz T, Strauss MC. (1998), Children and youth and horticultural therapy practice. In: Simson SP, Strauss MC (eds). Horticulture as Therapy: Principles and Practice. New York: The Food Products Press, 1998, 199-230.

Peters, P. (2003)“Here For The Children.” Texas Architect 53, no. 1: 22-25.

Phenice,L.\&Griffore,R.(2003).Young children and the natural world. Contemporary Issues in early childhood,4(2),167-178.

Piaget, J. (1962). Play, dreams and imitation in childhood. New York: W.W. Norton.

Plympton, P., S. Conway, and K. Epstein. (2000), “ Daylighting In Schools: Improving Student Performance And Health At A Price Schools Can Afford." Paper Presented At The American Solar Energy Society Conference, Madison, Wisconsin, June 16.

Prescott, E. (1987). The physical environment and cognitive development in child-care centers.In: Weinstein, C. S. and David, T. G. eds. Spaces for Children, New York: Plenum Press, 73-87.
Pyle, Robert (2002)," Eden in a Vacant Lot: Special Places, Species and Kids in Community of Life", in Children and Nature: Psychological, Sociocultural and Evolutionary Investigations. Kahn, P.H. \& Kellert, S.R. (eds), MIT Press, Cambridge, MA Reicher, D. (2000), “Nature's Design Rules: Leading The Way Toward Energy-Efficient Schools." Learning By Design. (2000),

Rice, A. J. (1953), “What Research Knows About Color In The Classroom." Nation's Schools 52, no. 5,: 1-8.

Rittner-Heir, R. M.(2002), “Color And Light In Learning." School Planning And Management 41, no. 2,: 60-61.

Romney, B. M. (1975). "The Effects Of Windowless Classrooms On The Cognitive And Affective Behavior Of Elementary School Students." ERIC Document Reproduction Service, ED 126622.

Rubin,K.H.,Fein,G.G.,\&Vandenberg,B.(1983). Play.In E.M.Hetherington(ED),Handbook of child psychology ( $4^{\text {th }}$ ed.,vol.4,pp.694-774). New York: John Wiley.

Said, Ismail (2007),Architecture for Children: Understanding Children Perception towards Built Environment. In: Proceedings of International Conference Challenges and Experiences in Developing Architectural education in Asia, Islamic University of Indonesia, 8-10 June (Unpublished)

Schultz, P.W., Shriver, C., Tabanico, J.J. \& Khazian, A.M. (2004), "Implicit Connections with Nature”, Journal of Environmental Psychology, 24(1), 31-42

Sherman, L. "Lighting The Way To Learning. (2001)" Northwest Education Magazine 6, no. 4

Smilansky, S. (1968). The effects of sociodramatic play on disadvantaged preschool children. New York: Wiley.

Sobel, David (1996) Beyond Ecophobia: Reclaiming the Heart of Nature Education, The Orion Society, Great Barrington, MA

Sobel, David (2002), Children's Special Places: Exploring the Role of Forts, Dens, and Bush Houses in Middle Childhood, Wayne State University Press, Detroit, MI Sobel, David (2004). Place-Based Education, Connecting Classrooms \& Communities, The Orion Society, Great Barrington, MA 
Sylva,K.(1974). The relationship between play and problem solving in children 3-5 years old.unpublished doctoral dissertation, Harward University, Cambridge,MA. Sylva,K.,Bruner,J.S.,\&Genova,P.(1976). The role of play in the problem solving of children 3-5 years old. In J.S.Bruner\&K. Sylva(Eds.), Play: its role in development and evolution (pp.244-260). New York: Basic Books

Symons CW, Cinelli B, James TC et al. (1997), Bridging student health risks and academic achievement through comprehensive school health programs. J Sch Health 1997; 67: 220-7.

Tanner, C. K. (2000), “The Influence Of School Architecture On Academic Achievement.” Journal of Educational Administration 38, no. 4: 309-330.

Tanner, C. K. and S. Langford. (2003). The Importance Of Interior Design Elements As They Relate To Student Outcomes. Dalton, GA: Carpet and Rug Institute, ERIC Document Reproduction Service, ED 478177.

Taylor, A.F., Wiley, A., Kuo, F.E., \& Sullivan, W.C. (1998), “Growing Up in the Inner City: Green Spaces as Places to Grow”, Environment and Behavior, 30(1), 3-27
Taylor, A.F., Kuo, F.E. \& Sullivan, W.C. (2001), "Coping with ADD: The Surprising Connection to Green Play Settings", Environment and Behavior, 33(1), 54-77

Taylor, A.F., Kuo, F.E. \& Sullivan, W.C. (2002), "Views of Nature and Self-Discipline: Evidence from Inner City Children", Journal of Environmental Psychology, 22, 49-63

Titman, W.(1994), Special Places: Special People. Surrey: WWF UK.

Wachs,T.D.(1978). The relationship of infants' physical environment to their binet performance at two and one half years, international journal of behavioral development,1,51-65.

Wells NM.(2000), At home with nature: effects of 'greenness' on children's cognitive functioning. Environ Behav; 32: 775-95.

Wells NM, Evans GW. (2003),Nearby nature: a buffer of life stress among rural school children. Environ Behav 2003; 35: 311-330 Wilson, Ruth (1993), Fostering a Sense of Wonder During the Early Childhood Years, Greyden, Columbus, $\mathrm{OH}$

Wilson, Ruth A. (1997). "The Wonders of Nature - Honoring Children's Ways of Knowing”, Early Childhood News, 6(19)
Yarrow,L.J.,Rubinstein.J.L.\&Pederson, F.A.(1975).Infant and environment: Early cognitive and motivational development. New York: Halsted.

\section{References of figures:}

Fig 1: http://www.designshare.com/index. $\mathrm{php} /$ projects/henson-valley-montessorischool/images@4861 (accessed: 5 May 2012)

Fig 2: http://www.designshare.com/index. $\mathrm{php} /$ projects/pistorius-schule/images@4008 (accessed: 5 May 2012)

Fig 3: http://www.designshare.com/index. php/projects/paschalisschool/images@101 (accessed: 5 May 2012)

Fig 4: http://www.schoolyards.org/gallery. BeforeAndAfterPhotos.php (accessed: 5 May 2012)

Fig 5: http://www.designshare.com/index. php/projects/gems-world-school/images@4357 (accessed: 5 May 2012)

Fig 6: http://www.designshare.com/index. php/projects/moreland-hills-elementary/ images@2272 (accessed: 5 May 2012) 